\title{
Education about Learning Motivation, Time Management, and Pocket Money Management for Students of Strada Bhakti Utama Junior High School
}

\author{
Ari Setiyaningrum ${ }^{1 *}$ \\ ${ }^{1}$ Master of Management Department, Faculty of Economics and Business, Atma Jaya Catholic \\ University of Indonesia, Jakarta, Indonesia \\ ari.setiyaningrum@atmajaya.ac.id \\ Lina Salim ${ }^{2}$, Novia Utami ${ }^{3}$ \\ ${ }^{2}$ Master of Management Department, Atma Jaya Catholic University of Indonesia, Jakarta, Indonesia \\ ${ }^{3}$ Department of Management, Atma Jaya Catholic University of Indonesia, Jakarta, Indonesia \\ lina.salim@atmajaya.ac.id, novia.utami@atmajaya.ac.id
}

(Received October 15, 2021, accepted November 02, 2021)

\begin{abstract}
Covid-19 pandemic has raised several problems faced by students including declining motivation to learn, lack of time to do independent assignments, and reduced amount of pocket money given by parents. This community service (CS) was designed to assist students in overcoming these problems through online education and training activities to increase students' learning motivation and increase literacy on time management and pocket money management. Partners in this CS activity were 53 students of Strada Bhakti Utama Junior High School. The method of implementing activities used are counselling, exercises, and questions and answers. The success rate of this CS program was measured from analysis of the pre-test and post-test results conducted before and after the activity as well as from assessment of students' accuracy in answering online quiz questions. Based on results of pre-test and posttest analysis, CS activities through education and training on learning motivation, time management, and pocket money management were proven to be able to increase students' understanding of the importance of managing pocket money, saving, managing time, motivation, and source of motivators in life. In addition, based on the results of online quiz assessments, most students could answer correctly the questions about the material presented.
\end{abstract}

Keywords: learning motivation; pocket money management; time management 


\section{Introduction}

The Covid-19 pandemic, which has hit many countries including Indonesia, has shifted a lot of aspects. One of the major shifts includes the teaching and learning activity. During the implementation of a large-scale social restriction and the public activity restriction in some regions to prevent the spread of Covid-19 viruses, schools have been forced to stop face-toface learning and implement distance learning since March 16, 2020 (Kamil, 2020). As a result, students have been forced to study from home.

According to the Indonesian Child Protection Commission, the implementation of distance learning is less effective (Sudjatmiko, 2020). Parents, and the fact that not all of them are technologically adept to adapt to online learning, are among the reasons why distance learning may seem less effective. Parents also show concerns related to children's dependency and addiction to gadgets as a result of prolonged use of the equipment. As to children, the Indonesian Child Protection Commission survey results show that $76.7 \%$ of students admitted they dislike the distance learning system while $81.8 \%$ of students claimed that, more often than not, distance learning is often designed with students working on assignments without teachers delivering materials. Being in such conditions, students feel demotivated to learn online.

The Covid-19 pandemic has raised a number of issues among school students. Firstly, students reported lower motivation in learning due to boredom of online learning routine which requires them to sit in front of the laptop or smartphone for hours every day. Secondly, students complained that increased workload has forced them to manage their time better to make sure they finish all assignments in time. Thirdly, the pandemic has affected the economy of the family with parents, either working for a company or running a business, earning a lower salary or generating lower business profit than normal. Some parents were even laid off or fired. With parents generating lower income, students were forced to receive less pocket money than usual. Living in this situation, students must manage the money they received from their parents wisely.

Motivation describes ones' driving force to behave or act towards their goals (Masni, 2015). Learning motivation refers to all forces that drive students to learn continuously in order to achieve their goals. Motivation is sourced both internally and externally (Masni, 2015). When sourced internally, it is called intrinsic motivation, but when sourced externally, it is extrinsic 
motivation. Students having intrinsic motivation study hard to improve understanding and gain more knowledge. On the other hand, students with extrinsic motivation study hard to earn rewards such as praises, respects, and honours.

Time management is critical for everyone, including students. Distance learning requires students to organize and manage their time better. Efficient time management is the key to success in learning, and therefore, students need to manage their time effectively (Nadinloyi et al., 2013). Conceptually speaking, time management is a series of habit or behaviour that can be learned and grown through improved knowledge, training, or implementation (MacCann et al., 2012). Time management shows one's ability to make priority based on the importance of various aspects in daily life (Agiani et al., 2015). Time management is also related to one's ability to use and allocate time to various activities properly (Prabandari, 2020). Principally, time management is a process of planning, organizing, directing, and controlling time effectively and efficiently. Time management helps students determine sequence of activities, starting from the most to the least important, and allocate the time needed to finish everything. Besides time management, students must understand the importance of managing their pocket money. Pocket money management describes the way students manage the money they receive from parents to purchase items they see important and worth buying. Principally, pocket money management helps students spend money only on items they really need and encourages them to save some of it. Frequency of giving out pocket money to children as well as the amount given greatly influence the way students manage their money (Ratri \& Khoiriyah, 2014). The less frequent parents give pocket money to their children, the bigger the opportunity the children must learn to manage their finance. Speaking of the amount, the bigger the amount of money given, the higher the tendency for students to live extravagantly and thus the higher the risks of them losing money. Pocket money management helps to train students to save money and decide on what to buy based on priority, starting from the most important to the least, and allocate the money to buy the items.

To help solve the problems, the CS team provides the service partner, i.e., students, with a solution that is online educational activity and training aiming at increasing students learning motivation and literacy in time and money management. This educational activity and training involved students in the seventh, eighth, and ninth grades at Strada Bhakti Utama Jakarta Junior High School. It is expected that upon completion of this educational activity and training 
students have the spirit and motivation to study, the ability to organize and manage their time better, and the ability to organize and manage their pocket money wisely.

\section{Methods}

The community service (CS) program began with the CS team obtaining a permit one (1) month before the event started. The team then coordinated with the principal of Strada Bhakti Utama Jakarta Junior High School to prepare for the event. The CS team worked together with the school principal and four (4) teachers responsible for organizing students during the event. The program involved online educational activity and training using Zoom meeting application due to restrictions to hold a face-to-face meeting during the pandemic.

A pre-test was carried out prior to the event to assess students' understanding of learning motivation, time management, and pocket money management before they participated in the educational activity and training. This event used methods including outreach, exercise, and question and answer.

An outreach was done by speakers, i.e., lecturers and students of the Management study program the Faculty of Economics and Business Atma Jaya Catholic University of Indonesia to bring information and materials to students. In this session, speakers presented the concept of learning motivation, time management, and pocket money management, played videos, and gave examples of how to implement the concept in daily life to help students understand the given materials.

An exercise was given to measure the success of the program, which was done by evaluating students' understanding of the materials presented by the speakers in each session. The CS team organized an online quiz using Kahoot! application at the end of each outreach session about learning motivation, time management and pocket money management. To show appreciation, the team awarded participants who were active and able to answer the questions quickly and correctly with internet data packages.

A question-and-answer session was held to give participants opportunity to ask questions and share opinions or experiences related to learning motivation, time management, and pocket money management with each other. Upon completion of the event, a post-test was conducted 
Education about Motivation, Time Management, and Pocket Money Management for Students of Strada Bhakti Utama 115 Junior High School

to see whether participants' understanding of learning motivation, time management, and pocket money management increased after participating in the educational activity and training.

In this CS activity, the CS team only uses descriptive statistics because the main purpose of this activity is to find out whether there is an increase in participants' understanding of learning motivation, time management, and pocket money management. The CS team did not analyze whether the educational and training activities provided could affect changes in participant behavior.

\section{Results and Discussions}

This CS activity was carried out online in the form of education and training through the Zoom meeting application on Saturday, May 29, 2021. Participants in the CS activity were 53 students in grades VII, VIII, IX of SMP Strada Bhakti Utama Jakarta consisting of $61.5 \%$ female participants and 38.5\% male participants. CS activities also involve four (4) teachers who assist the CS Atma Jaya Catholic University of Indonesia team in monitoring and evaluating activities related to the assigned tasks. Documentation of the implementation of giving education and training activities on learning motivation, time management, and pocket money management is shown in Figure 1 and Figure 2.

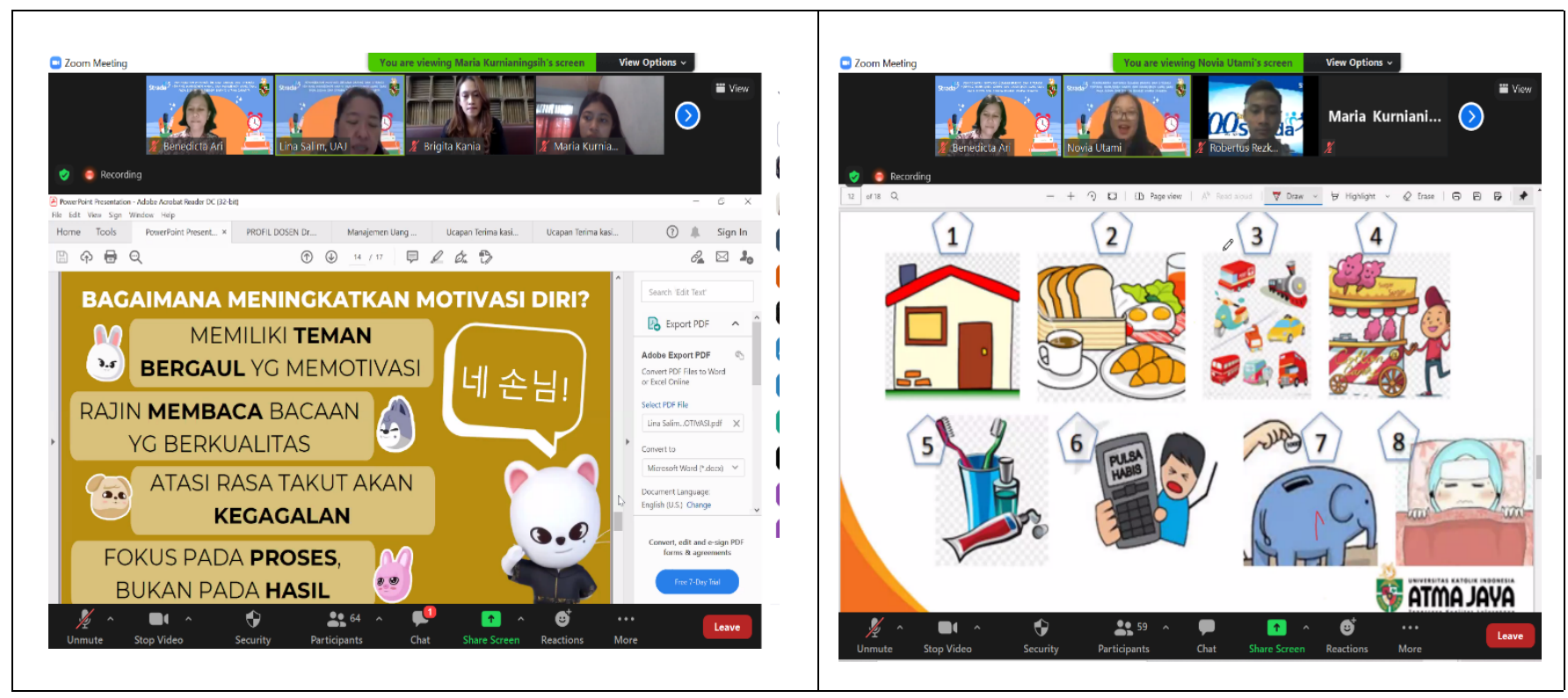

Fig. 1. Material presentation by UAJ's speakers 


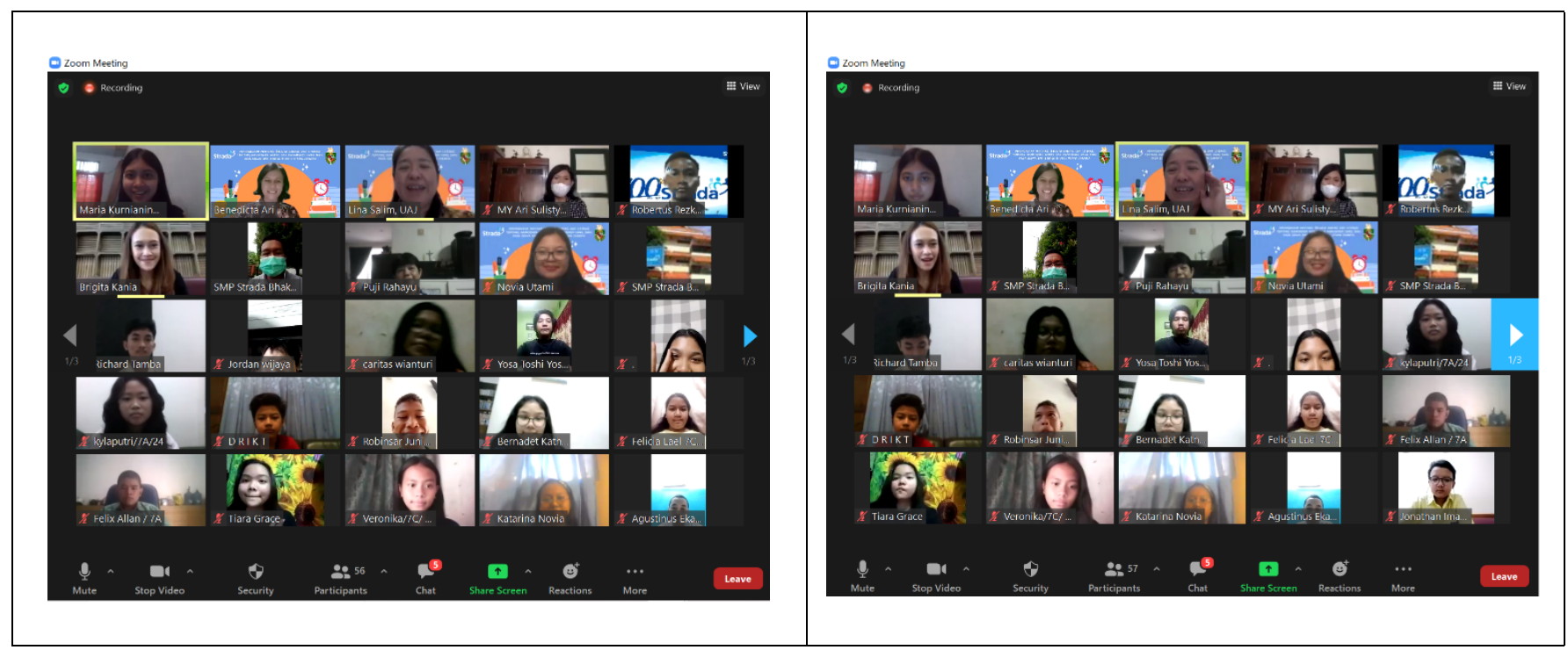

Fig. 2. Picture of the CS team with the participants

The success rate of the CS program is measured by the results' analysis of the pre-test and posttest conducted before and after the CS activity. The CS team conducted a comparative analysis of the average scores from the pre-test and post-test answers to determine the participants' level of understanding about learning motivation, time management, and pocket money management between before and after being given the education and training. Pre-test and post-test data were processed using compared-means analysis with SPSS statistical software. The results of evaluating students' understanding of learning motivation, time management, and pocket money management are shown in Table 1 .

Table 1. Results of comparative analysis of pre-test and post-test average values participants understanding of learning motivation, time management, and pocket money management

\begin{tabular}{|c|c|c|c|c|c|c|}
\hline \multicolumn{2}{|c|}{ Participants } & $\begin{array}{c}\text { Pocket Money } \\
\text { Management }\end{array}$ & Saving & Time Management & Motivation & $\begin{array}{c}\text { Source of } \\
\text { Life } \\
\text { Motivator }\end{array}$ \\
\hline \multirow{3}{*}{ pre-test } & Mean & 3.96 & 4.81 & 4.13 & 4.08 & 4.32 \\
\hline & $\mathrm{N}$ & 53 & 53 & 53 & 53 & 53 \\
\hline & $\begin{array}{l}\text { Std. } \\
\text { Deviation }\end{array}$ & 0.808 & 0.395 & 0.921 & 1.089 & 0.850 \\
\hline \multirow{3}{*}{ post-test } & Mean & 4.68 & 4.89 & 4.87 & 4.74 & 4.66 \\
\hline & $\mathrm{N}$ & 53 & 53 & 53 & 53 & 53 \\
\hline & $\begin{array}{l}\text { Std. } \\
\text { Deviation }\end{array}$ & 0.644 & 0.375 & 0.394 & 0.445 & 0.706 \\
\hline \multirow{3}{*}{ Total } & Mean & 4.32 & 4.85 & 4.50 & 4.41 & 4.49 \\
\hline & $\mathrm{N}$ & 106 & 106 & 106 & 106 & 106 \\
\hline & $\begin{array}{l}\text { Std. } \\
\text { Deviation }\end{array}$ & 0.811 & 0.385 & 0.796 & 0.892 & 0.796 \\
\hline \multicolumn{2}{|c|}{$\begin{array}{l}\text { Percentage of } \\
\text { increasing value } \\
\text { before and after } \\
\text { education and } \\
\text { training }\end{array}$} & 0.72 & 0.08 & 0.74 & 0.66 & 0.34 \\
\hline
\end{tabular}

Source: Data Processed (2021) 
Table 1 shows that there is an increase in the average value of students' understanding of the importance of pocket money management, saving, time management, motivation, and sources of life motivator. The average value of students' understanding of the importance of pocket money management before being given education and training was 3.96 and after being given education and training increased to 4.68. Regarding the importance of saving, the results of the analysis show that the average value of students' understanding before being given education and training is 4.81 and after being given education and training it increases to 4.89. Related to the time management, the results of the analysis show that the average value of students' understanding before being given education and training is 4.13 and after being given training education increases to 4.87. Regarding the importance of motivation, the results of the analysis show that the average value of students' understanding before being given education and training is 4.08 and after being given education and training it increases to 4.74 . The results of motivations factor show that the average value of students' understanding before being given education and training is 4.32 and after being given education and training, the outcome increases to 4.66 .

Apart from the results of the pre-test and post-test analysis, the success rate of the CS program is measured by assessing the students' accuracy in answering online quiz questions through Kahoot! application. The results of the quiz assessments showed that most of the students had answered the questions correctly. Figure 3 presents documentation of asking questions through online quizzes for the purpose of evaluating whether participants understand the material presented by the resource persons in each session.

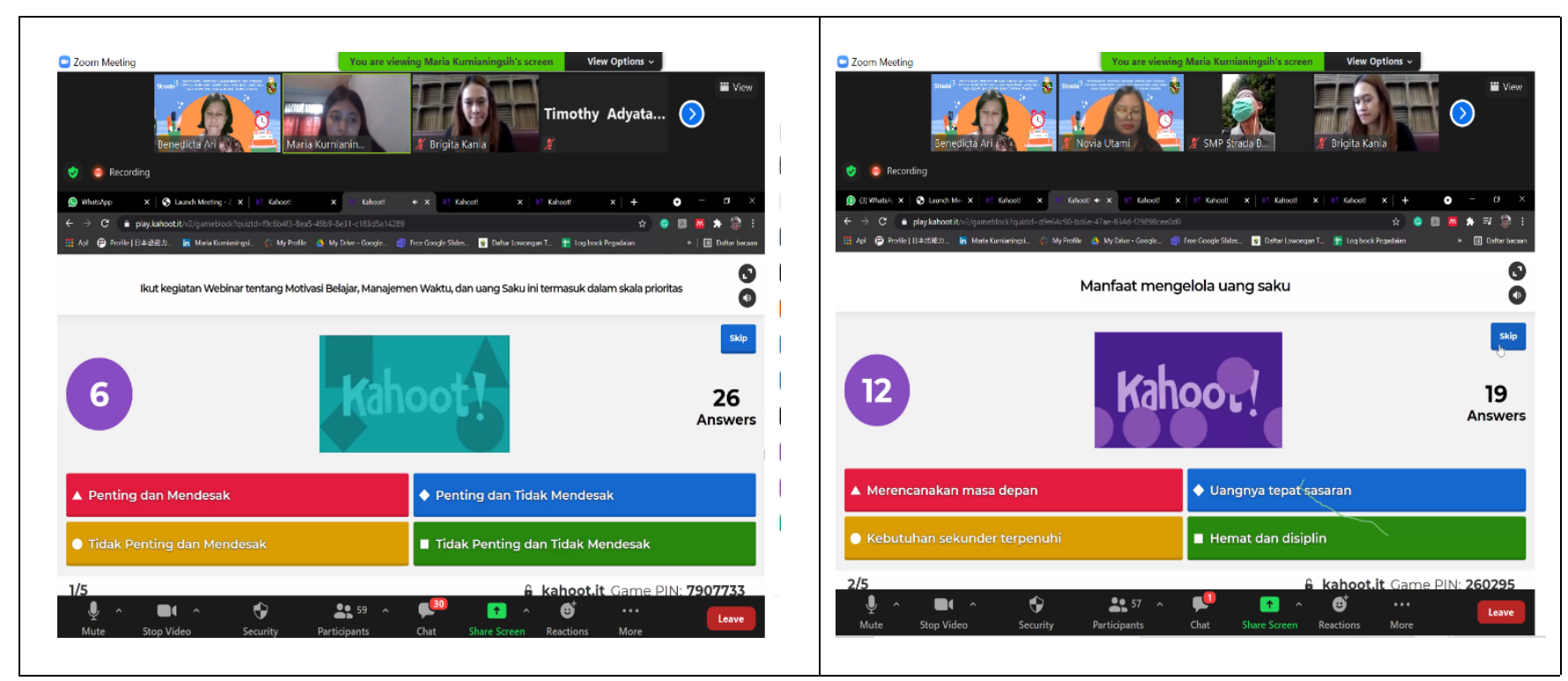

Fig. 3. Giving questions situation through online quiz 


\section{Conclusion}

The conclusion obtained from this CS is that education and training on learning motivation, time management, and pocket money management carried out in this CS activity proved to be able to upsurge students' understanding of the importance of managing pocket money, saving, managing time, motivation, and sources of life motivators. Generally, the participants considered that they were satisfied with the material presented in the education and training activities about learning motivation, time management, and pocket money management. Participants also considered that the education and training activities on learning motivation, time management, and pocket money management were very relevant and useful to be applied in daily life and participants hoped that these educational and training activities could be continued in the future.

Suggestions that need to be considered for the implementation of further CS activities are related to the timing of the implementation of activities that should be carried out on school days between Monday to Friday so that more participants can be involved. This CS was carried out on Saturday which is a school holiday and not many students are enthusiastic about participating in activities on their day off. In addition, education and training on learning motivation, time management, and pocket money management should be carried out regularly, especially at the beginning of each semester so that students are motivated in learning (specifically online learning), able to manage time and manage pocket money better. In the future, education and training activities on learning motivation, time management, and pocket money management can be carried out by involving high school students.

\section{Acknowledgements}

Sincere thanks to Strada Bhakti Utama Jakarta Junior High School for supporting this CS program. Special thanks to Brigita Kania Novia Putri, S.M., and Maria Kurnianingsih, S.M., two (2) former students (now alumni of FEB-Management Unika Atma Jaya) for their assistance during implementation of this program.

\section{References}

Agiani, P., Nursetiawati, S., \& Muhariyati, M. (2015). Analisis Manajemen Waktu pada Ibu Bekerja. Jurnal Kesejahteraan Keluarga dan Pendidikan, 4(1), 27-35. 
Kamil, I. (2020). Kilas Balik Pembelajaran Jarak Jauh akibat Pandemi Covid-19. Retrieved on March 11, 2021 through https://nasional.kompas.com/read/2020/09/03/10063201/ kilas-balik-pembelajaran-jarak-jauh-akibat-pandemi-covid-19?page=all

MacCann, C., Fogarty, G. J., \& Roberts, R. D. (2012). Strategies for success in education: Time management is more important for part-time than full-time community college students. Learning and Individual Differences, 22(5), 618-623.

Masni, H. (2015). Strategi Meningkatkan Motivasi Belajar. Dikdaya, 05(01), 34-45.

Nadinloyi, K. B., Hajloo, N., Garamaleki, N. S., \& Sadeghi, H. (2013). The Study Efficacy of Time Management Training on Increase Academic Time Management of Students. Procedia - Social and Behavioral Sciences, 84, 134-138.

Prabandari, A. I. (2020). Manajemen Waktu adalah Cara Menggunakan Waktu dengan Efektif, Ketahui Manfaatnya. Retrieved on March 11, 2021 through https://www.merdeka.com/jateng/manajemen-waktu-adalah-cara-menggunakan-waktudengan-efektif-ketahui-manfaatnya-kln.html?page $=2$

Ratri, M. E. \& Khoiriyah, R. (2014). Mengenalkan Uang Lewat Manajemen Uang Saku. Retrieved on March 11, 2021 through https://money.kompas.com/read/2014/09 /11/093400926/Mengenalkan.Uang.Lewat.Manajemen.Uang.Saku.1.?page=all\#page2

Sudjatmiko, T. (2020). Survey KPAI, Pembelajaran Jarak Jauh Dianggap Memberatkan dan Membosankan. Retrieved on March 11, 2021 through https://www.krjogja.com/ peristiwa/nasional/survey-kpai-pembelajaran-jarak-jauh-dianggap-memberatkan-danmembosankan/2/ 